\title{
ELECTROCATALYSIS FOR OXYGEN ELECTRODES IN FUEL CELLS AND WATER ELECTROLYZERS FOR SPACE APPLICATIONS
}

\author{
Jai Prakash, Donald Tryk and Ernest Yeager \\ Case Center for Electrochemical Sciences \\ and the Chemistry Department \\ Case Western Reserve University \\ Cleveland, Ohio 44106
}

The lead ruthenate pyrochlore $\mathrm{Pb}_{2} \mathrm{Ru}_{2} \mathrm{O}_{6} .5$ in both high and low area forms has been characterized using thermogravimetric analysis, $X$-ray photoelectron spectroscopy, $\mathrm{X}$-ray diffraction, cyclic voltammetry and $\mathrm{O}_{2}$ reduction and generation kinetic-mechanistic studies. Mechanisms are proposed. Compounds in which part of the $\mathrm{Ru}$ is substituted with Ir have also been prepared. They exhibit somewhat better performance for $\mathrm{O}_{2}$ reduction in porous gas-fed electrodes than the unsubstituted compound. The anodic corrosion resistance of pyrochlore-based porous electrodes was improved by using two different anionically conducting polymer overlayers, which slow down the diffusion of ruthenate and plumbate out of the electrode. The $\mathrm{O}_{2}$ generation performance was improved with both types of electrodes. With a hydrogel overlayer, the $\mathrm{O}_{2}$ reduction performance was also improved.

\section{INTRODUCTION}

In most instances separate electrocatalysts are needed to promote the reduction of $\mathrm{O}_{2}$ in the fuel cell mode and to generate $\mathrm{O}_{2}$ in the energy storage- water electrolysis mode in aqueous electrochemical systems operating at low and moderate temperatures $\left(\mathrm{T} \leq 200^{\circ} \mathrm{C}\right.$ ). This situation arises because, even with relatively high performance catalysts, the $\mathrm{O}_{2}$ reduction and generation reactions are still quite irreversible with much overpotential. The potentials of the $\mathrm{O}_{2}$ electrode in the cathodic and anodic modes are separated by typically $0.6 \mathrm{~V}$ and the states of the catalyst surface are very different. Interesting exceptions are the lead and bismuth ruthenate pyrochlores in alkaline electrolytes. These catalysts have high catalytic activity for both $\mathrm{O}_{2}$ reduction and generation (1-6). Furthermore, rotating ring-disk electrode measurements provide evidence that the $\mathrm{O}_{2}$ reduction proceeds by a parallel four-electron pathway (6). The ruthenates can also be used as self-supported catalysts to avoid the problems associated with carbon oxidation, but the electrode performance so far achieved in our laboratory is considerably less.

At the potential involved in the anodic mode the ruthenate pyrochlores have substantial equilibrium solubility in concentrated alkaline electrolyte. This results in the loss of catalyst into the bulk solution and a decline in catalytic

${ }^{*}$ This work was supported by the NASA-Lewis Research Center under Contract No. NAG3 -964 . 
activity. Furthermore, the hydrogen generation counter electrode may become contaminated with reduction products from the pyrochlores (lead, ruthenium).

A possible approach to this problem is to immobilize the pyrochlore catalyst within an ionically conductive solid polymer, which would replace the fluid electrolyte within the porous gas diffusion $\mathrm{O}_{2}$ electrode. For bulk alkaline electrolytes, an anion exchange polymer is needed with a transference number close to unity for the $\mathrm{OH}^{-}$ion. Such a membrane may not block completely the transport of the lead and ruthenium, which are expected to be in complex anionic forms. Preliminary short term measurements with lead ruthenates using either 1) a partially fluorinated anion exchange membrane as an overlayer on the porous gas-fed electrode or 2) a hydrogel coating on the porous electrode indicate lower anodic polarization and similar cathodic polarization. With the hydrogel coating, there is also some enhancement of the performance at higher current densities.

\section{EXPERIMENTAL}

The pyrochlores were synthesized at CWRU using the alkaline solution technique of Horowitz et al (3). Samples of $\mathrm{Pb}_{2} \mathrm{Ru}_{2} \mathrm{O}_{6} .5$ and $\mathrm{Pb}_{2}\left[\mathrm{Ru}_{1} .67 \mathrm{~Pb}_{0} .33\right] \mathrm{O}_{6}$.5 were also provided by Exxon. This method involves the reaction of the appropriate metal cations by precipitation and subsequent crystallization of the precipitate in a liquid alkaline medium ( $4 \mathrm{M} \mathrm{KOH}$ ) in the presence of $\mathrm{O}_{2}$ at $-75-90^{\circ} \mathrm{C}$. The salts used were $\mathrm{Ru}(\mathrm{NO})\left(\mathrm{NO}_{3}\right)_{3}$, in aqueous solution, 1.58 (w/v) from $\mathrm{strem}, \mathrm{IrCl}_{3} \cdot 3 \mathrm{H}_{2} \mathrm{O}$ (Aldrich, Gold Iabe1) and $\mathrm{Pb}\left(\mathrm{CH}_{3} \mathrm{COO}\right)_{2} \cdot 3 \mathrm{H}_{2} \mathrm{O}$ (MCB, reagent grade). The salts were added in the appropriate amounts to achieve the desired stoichiometries. The reactions were carried out for $24-72 \mathrm{~h}$, until the supernatant solution was free of detectable amounts of the reactant metal ions. The suspension was filtered and washed with water and glacial acetic acid. The X-ray diffraction (XRD) was measured after a heat treatment (HT) in air at $300-350^{\circ} \mathrm{C}$ for $12 \mathrm{~h}$. In some cases XRD was also run prior to the HT.

Thermogravimetric analysis was performed on a Perkin-Elmer 7 Series Thermal Analysis System with $\mathrm{O}_{2}$ and $\mathrm{N}_{2}$ purges at a temperature ramp rate of $15^{\circ} \mathrm{C} \mathrm{min-1.} \mathrm{X}$ ray photoelectron spectroscopy was obtained using a Varian IEE- 15 instrument.

A modification of the ring-disk electrode (RRDE) technique was used in which a thin PTFE-bonded porous coating of the pyrochlore was applied to a basal plane pyrolytic graphite disk, which was slightly recessed. PTFE suspension (Teflon T30B, Du Pont) was diluted with water and ultrasonically agitated with the pyrochlore and filtered with a $1 \mu \mathrm{m}$ pore size polycarbonate filter membrane (Nucleopore). The resulting mixture was 5 wt $\&$ in PTFE solids. The semi-moist paste was kneaded with a spatula and then applied to the disk (either 0.196 or $0.45 \mathrm{~cm}^{2}$ ) and spread evenly. Excess material was carefully removed from the edge of the disk. The layer was not allowed to dry in order to avoid cracking of the layer and was placed in the electrolyte solution. The amount of pyrochlore in the layer was determined after the experiment by first washing it in water, removing it, drying and weighing. The typical loading was $4-6 \mathrm{mg} \mathrm{cm}{ }^{2}$. The Au ring had a collection efficiency $\mathrm{N}$ of 0.177 . The Teflon electrochemical cell had separate compartments for the working RDE or RRDE electrode, counter electrode ( $\mathrm{Au}$ ) and reference electrode ( $\mathrm{Hg} / \mathrm{HgO}, 1 \mathrm{M} \mathrm{OH}^{-}$). The $\mathrm{KOH}$ solution was prepared from the solid (Fluka, puriss., p.a.) by dilution with triply distilled reverse osmosis water. 
Porous gas-fed electrodes were fabricated as follows. Teflon T30B suspension was diluted approximately to $2 \mathrm{mg} \mathrm{cm}^{-3}$ in water and slowly added to an aqueous suspension of $38 \mathrm{mg}$ of pyrochlore and $35 \mathrm{mg}$ of air-oxidized $\left(-1 \mathrm{~h}\right.$ at $\left.600^{\circ} \mathrm{C}\right)$ Shawinigan black (Chevron Chemical Co., Olefins and Derivatives Div., Houston, Texas). The suspension was filtered using a $1 \mu \mathrm{m}$ pore size filter membrane. The resulting paste was kneaded with a spatula until slightly rubbery, shaped into a $1.75 \mathrm{~cm}$ diameter disk in a stainless steel die using hand pressure and then pressed at a pressure of $-100 \mathrm{~kg} \mathrm{~cm}-2$. The disk was applied to a $0.5 \mathrm{~mm}$ thick disk of Teflon-carbon black hydrophobic backing material containing silver-plated nickel mesh (Electromedia Corp., Englewood, NJ). A final pressing was done at $-300 \mathrm{~kg}$ $\mathrm{cm}^{-2}$ at room temperature and then the disk was heat-treated at $-280^{\circ} \mathrm{C}$ for $2 \mathrm{~h}$ in flowing helium.

In some cases a $1.75-\mathrm{cm}$ diameter disk of a partially fluorinated anion exchange membrane material (Type 4035, RAI, Hauppage, NY) was pressed onto the electrolyte side of the electrode at $200 \mathrm{~kg} \mathrm{~cm}^{-2}$. In other experiments a mixture of poly(dimethyldiallylammonium)chloride (DMDAAC, 15 wt 8 in aqueous solution, Polysciences) and Nafion 117 ( 5 wtg in alcohol solution, Aldrich) was diluted by a factor of 6 by volume and painted onto the electrolyte side of the porous electrode and allowed to air-dry. The resulting hydrogel film was $-1.5 \mathrm{mg} \mathrm{cm}-2$.

The porous gas-fed electrode was placed in a special screw-cap-type Kel-F holder which holds the electrode vertically between a Pt foil current collector on the gas-side and a polyethylene-polypropylene rubber gasket on the electrolyte side. A stream of either air or $\mathrm{O}_{2}$ was directed at the back of the electrode. The area exposed to the electrolyte was $0.97 \mathrm{~cm}^{2}$. The $\mathrm{O}_{2}$ reduction measurements were performed galvanostatically in $5.5 \mathrm{M} \mathrm{KOH}$ at $25^{\circ} \mathrm{C}$ with a fastaction potentiostat (BC-1200, Stonehart Associates) using the current interruption method to correct for solution-phase IR drop external to the gas-fed electrode.

\section{$\underline{\text { RESULTS }}$}

Using the alkaline solution technique, a sample of $\mathrm{Pb}_{2} \mathrm{Ru}_{2} \mathrm{O}_{6} .5$ was prepared with a reasonably high area $\left(-35 \mathrm{~m}^{2} \mathrm{~g}^{-1}\right.$ ) and some evidence of crystallinity (X-ray diffraction) even without further heat treatment. After heat treatment at $-350^{\circ} \mathrm{C}$, the $\mathrm{X}$-ray diffraction became very well resolved. This result is important because heretofore it has been assumed that in order to achieve high surface areas, it is necessary to prepare the lead ruthenate with some substitution of the $\mathrm{Ru}$ with $\mathrm{Pb}$ (78). Such "lead-rich" compounds are known to exhibit decreasing stability as the amount of substitution increases (1). The $\mathrm{O}_{2}$ generation behavior of this $\mathrm{Pb}_{2} \mathrm{Ru}_{2} \mathrm{O}_{6} .5$ sample was significantly better than for other lower area samples of the same stoichiometry that were examined with gas-fed electrodes.

Further characterization studies for $\mathrm{Pb}_{2} \mathrm{Ru}_{2} \mathrm{O}_{6} .5$ are in progress in which the effect of the heat treatment is being examined. The thermogravimetric analysis (TGA), for example, indicates that $\sim 0.8$ moles of water are present before any heat treatment and are mostly removed at $800^{\circ} \mathrm{C}$. The $\mathrm{X}$-ray photoelectron spectra (XPS), however, did not show discernable changes in peak shapes or binding energies for $\mathrm{Ru}, \mathrm{Pb}$ and $\mathrm{O}$ over the temperature range $100^{\circ} \mathrm{C}$ to $500^{\circ} \mathrm{C}$, in which most of the water is lost. 


\section{Cyclic Voltammetry}

The cyclic voltammetry (CV) for the $\mathrm{Pb}_{2} \mathrm{Ru}_{2} \mathrm{O}_{6} .5$ thin porous coating is very complex. There is a large, gradually increasing anodic current on which are superimposed several small peaks (Fig. 1, a-e). On the back sweep there is a large cathodic peak. The charge under this peak $\left(2.7 \times 10^{-2} \mathrm{C}\right)$ corresponds to -12 of the total possible charge expected for a single electron transfer to each Ru atom in the coating ( $0.8 \mathrm{mg}$ or $1.1 \times 10^{-6} \mathrm{~mol}$, yielding $0.214 \mathrm{C}$ ). From the crystal structure (9), there are $4 \mathrm{Ru}$ atoms exposed on the face of each unit cell, whose edge is $10.253 \mathrm{~A}$. This corresponds to $-6.3 \times 10^{-10} \mathrm{~mol} \mathrm{~cm}-2$. The BET area of the $\mathrm{Pb}_{2} \mathrm{Ru}_{2} \mathrm{O}_{6} .5$ sample used for the $\mathrm{CV}$ experiment was $6.0 \mathrm{~m}^{2} \mathrm{~g}^{-1}$. Therefore, for a 0.8 $\mathrm{mg}$ sample, the surface area was $-48 \mathrm{~cm}^{2}$, corresponding to $3.02 \times 10^{-8}$ mol or $2.9 \mathrm{x}$ $10^{-3} \mathrm{C}$ for a 1 -electron process for surface Ru atoms only. This value is one order of magnitude less than the observed charge of $2.7 \times 10^{-2} \mathrm{C}$. One possible explanation is that -10 monolayers are involved in a 1 -electron process. On the other hand, for the valence states $\left(\mathrm{Pb}^{2+}\right)_{2}\left(\mathrm{Ru}^{4}, 5+\right)_{2}\left(\mathrm{O}^{2-}\right)_{6.5}$, the following oxidation processes are possible over the potential range:

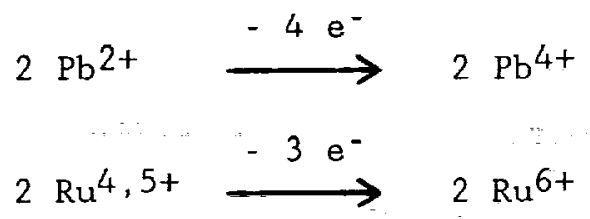

for a total of 7 electron transferred. This would still account for -1.5 monolayer, if all 7 electrons are involved. Therefore, it appears that the overall process involves not only the surface but also the bulk $(1.5<\mathrm{x}<10$ monolayers) of the material. If the process is indeed a 1 -electron process, it may be assigned to the $\mathrm{Ru}(\mathrm{IV}) / \mathrm{Ru}(\mathrm{V})$ transition proposed by Edgell et al (2). The existence of the smaller peaks has not been explained thus far but may involve $R u$ atoms on the surface of the oxide undergoing successive electron transfers with both $\mathrm{Pb}$ and $\mathrm{Ru}$ going to higher valence states.

\section{oxygen reduction}

The polarization curves for $\mathrm{O}_{2}$ reduction on a thin porous coating of $\mathrm{Pb}_{2} \mathrm{Ru}_{2} \mathrm{O}_{6} .5$ at a series of rotation rates are shown in Fig. 2. The corresponding ring currents for peroxide oxidation are very small, reaching a maximum of only $\sim 5$ of the disk current (corrected for $N$ ) at the most negative potentials.

Kinetic analysis of the ring-disk results using the method of Wroblowa et al. (10) would lead to the conclusion that the $\mathrm{O}_{2}$ reduction is proceeding via the direct 4-electron pathway to $\mathrm{OH}^{-}$. In addition, the slopes of the $\mathrm{i}^{-1}$ vs. $\mathrm{f}^{-1 / 2}$ plots (where $\mathrm{f}=$ rotation rate) correspond to an overall number of electrons being transferred of -3.8 . The porosity of the electrode causes complications in the interpretation of the data however. For example, if a catalyst is a good peroxide decomposer, it can appear that the $\mathrm{O}_{2}$ reduction is proceeding by a direct 4-electron pathway even though the reaction is proceeding by a series pathway, with $\mathrm{O}_{2}$ reduction to peroxide as the first step, followed by peroxide decomposition. overall this would yield 4 electrons. The reason for the possible confusion is that the peroxide requires a relatively long time to diffuse out of the porous layer and during this time has a good opportunity to decompose. Even so, the significant potential range over which there is negligible peroxide picked up at the ring rather strongly indicates a 4-electron process. 
Tafel plot of the mass-transport corrected currents for $f=2500 \mathrm{rpm}$ in the potential range of +0.06 to $-0.08 \mathrm{~V}$ is shown in Fig. 3. A linear relationship is obtained with a Tafel slope of $-0.063 \mathrm{~V}$ (decade)-1. This suggests a non-charge transfer step as rate determining following a fast outer-sphere electron transfer.

Oxygen reduction studies were also carried out over the $\mathrm{pH}$ range 11.9 to 13.9 keeping the ionic strength constant. The currents for $\mathrm{O}_{2}$ reduction increased with decreasing concentration of $\mathrm{OH}^{-}$. The half wave potential also became increasingly positive. The slopes of the mass transport-corrected Tafel plots were also almost identical over the above $\mathrm{pH}$ range. A reaction order of -0.5 with respect to $\mathrm{OH}^{-}$ concentration over this $\mathrm{pH}$ range was observed. This result together with the Tafel slope of $-0.06 \mathrm{~V}$ (decade) (d) $^{-1}$ is consistent with the following mechanism for $\mathrm{O}_{2}$ reduction on the $\mathrm{Pb}_{2} \mathrm{Ru}_{2} \mathrm{O}_{6} .5$ pyrochlore.

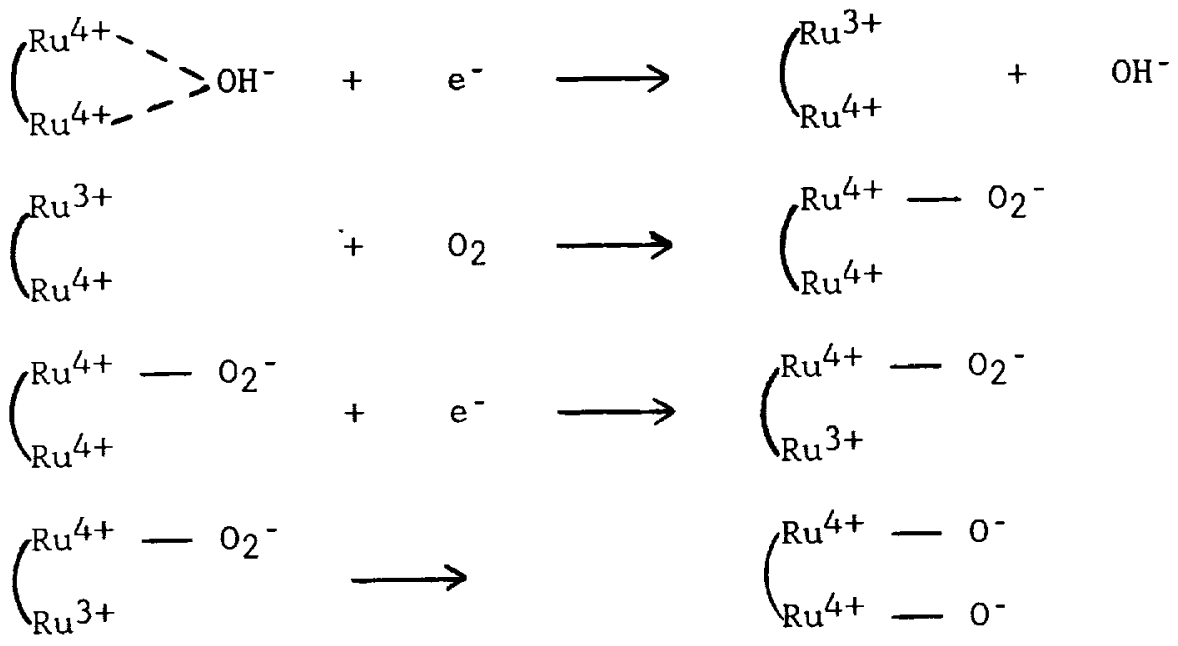

(Fast)

followed by a series of further steps resulting in the overall process

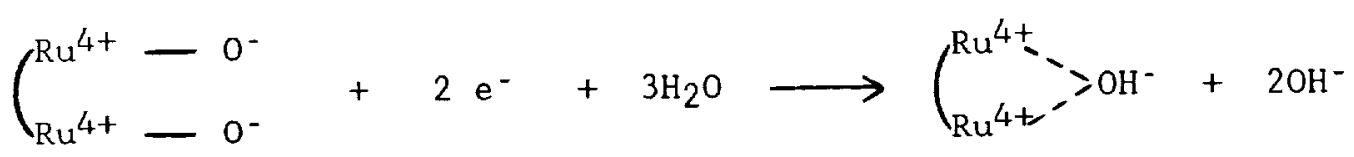

which would not generate solution-phase peroxide.

\section{Oxygen generation}

$\mathrm{O}_{2}$ generation studies were carried out over a range of $\mathrm{pH}$ (11 to 14) at a constant ionic strength. The catalyst was incorporated in a poraus electrode (geometric area $=4.8 \mathrm{~cm}^{2}$ ) using Teflon $\mathrm{T} 30 \mathrm{~B}$ as the binder with a Ni screen current collector and heat treated at $280^{\circ} \mathrm{C}$ for $2 \mathrm{~h}$ in an inert atmosphere. The Tafel slope at room temperature varied from 0.032 to $0.038 \mathrm{~V}$ (decade) ${ }^{-1}$. A reaction order of 1.0 was found with respect to $\mathrm{OH}^{-}$concentration over this $\mathrm{pH}$ range. A reaction mechanism consistent with the reaction order is proposed as follows. 


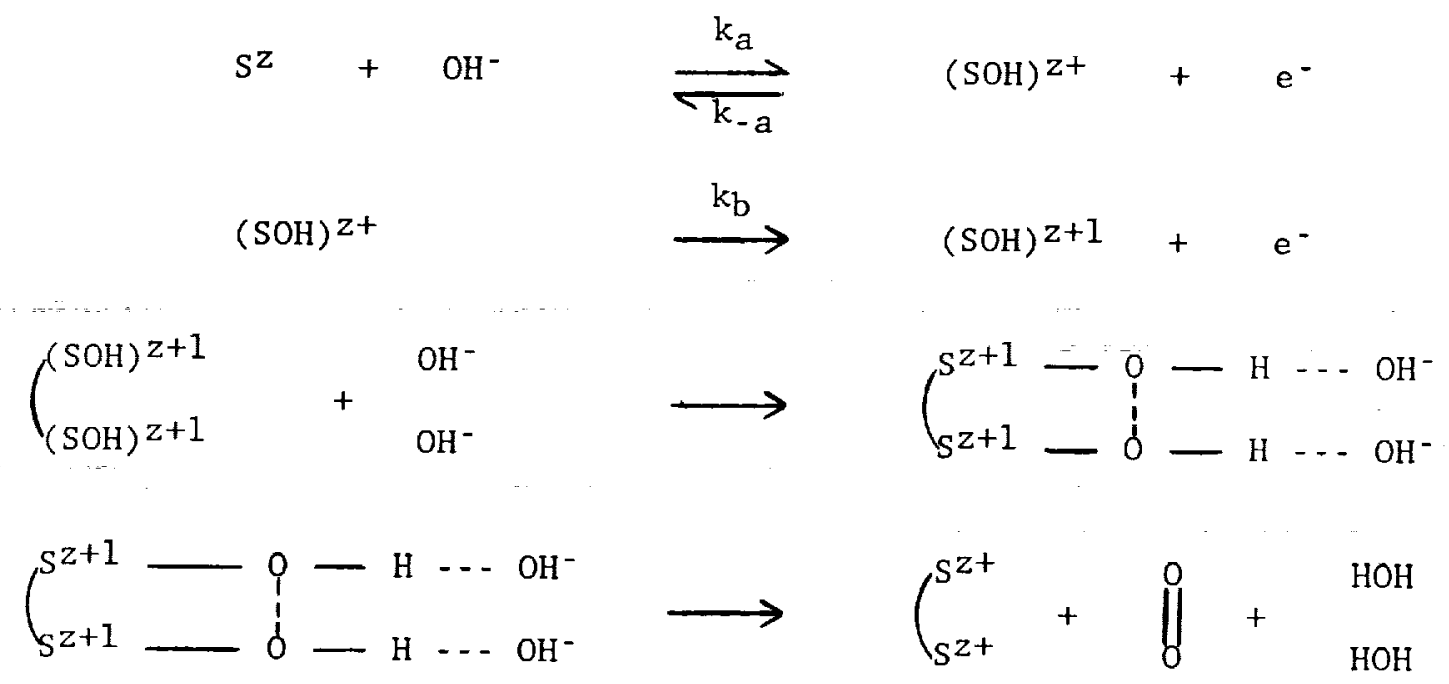

This mechanism is similar to the one proposed for $\mathrm{O}_{2}$ generation on $\mathrm{RuO}_{2}$ electrodes (11).

\section{Gas-fed electrode measurements}

The electrochemical behavior, including the $\mathrm{O}_{2}$ reduction and generation activity as well as the stability in the anodic mode can be modified by substituting a part of either the $\mathrm{Pb}$ or $\mathrm{Ru}$ with other metals. One such type of substitution which was examined is that of $\mathrm{Ir}$ for $\mathrm{Ru}$ in the $\mathrm{B}$ site. Ir is expected to be more resistent to anodic dissolution than $\mathrm{Ru}$ (13). The ionic radii are very similar (11) and the lattice parameters for $\mathrm{Pb}_{2} \mathrm{Ru}_{2} \mathrm{O}_{6} .5$ and $\mathrm{Pb}_{2} \mathrm{Ir}_{2} \mathrm{O}_{6} .5$ are very similar (9). Thus there is probably a continuous range of solid solutions possible. Horowitz et al. mentioned that such compounds are possible to prepare using the alkaline solution technique (7) but have not presented electrochemical results for compounds of this type. Two compounds were prepared in our laboratory and the $\mathrm{X}$-ray diffraction indicates a single pyrochlore phase.

Although the effects on the $\mathrm{O}_{2}$ reduction are slight, they are encouraging (Fig. 4). The effects on the $\mathrm{O}_{2}$ generation were also slight (Fig. 5). It is not clear at present to what extent these effects might be due to changes in the wetted catalyst surface area.

Another approach to inhibiting the anodic dissolution of $\mathrm{Ru}$ is to use a conductive solid ionomer either as replacement for the liquid electrolyte within the porous $\mathrm{O}_{2}$ cathode or as an overlayer on the solution side of the electrode. Even though the dissolved species are anionic, $\left(\mathrm{RuO}_{4}^{2-}, \mathrm{HPbO}_{2}{ }^{-}, \mathrm{PbO}_{3}^{2-}\right)$ they should diffuse relatively slowly in such ionomers due to size effects. Two types of ionomers were used in this preliminary work. The first was a partially fluorinated anion exchange membrane (RAI 4035) as an overlayer. The second was a hydrogel coating which consisted of a mixture of poly(dimethyldiallylammonium)chloride (DMDAAC) and Nafion (14). The RAI membrane exhibited a definite effect in slowing down the release of ruthenate into the solution when an electrode made from $\mathrm{Pb}_{2}\left[\mathrm{Ru}_{1} .67 \mathrm{~Pb}_{0.33}\right] \mathrm{O}_{6.5}$ was in the $\mathrm{O}_{2}$ generation mode.

The pre-cast ionomer layer was not expected to have a significant effect on 
the $\mathrm{O}_{2}$ reduction and this turned out to be the case (Fig. 6). With the hydrogel coating, however, the ionomers can come into more intimate contact with the catalyst in the porous layer and possibly improve the performance through an increase in the $\mathrm{O}_{2}$ concentration associated with the polymer fluorocarbon backbone. A small improvement in the performance for $\mathrm{O}_{2}$ reduction at high current densities was observed for the hydrogel-coated electrode and this is quite encouraging (Fig. 6). With both ionomers there was an improvement in the $\mathrm{O}_{2}$ generation performance (Fig. 7). This was not expected but can be explained by pointing out that the inhibition of the anodic dissolution would slow down the progressive changes in the surface composition of the material that would occur during the dissolution.

\section{ACKNOWLEDGEMENT}

This research has been supported by NASA through the Lewis Laboratory and the Department of Energy through a subcontract with Lawrence Berkeley Laboratory. Samples of two pyrochlores were kindly supplied by $\mathrm{Dr}$. H. S. Horowitz of Exxon. The assistance of $\mathrm{Mr}$. Wesley Aldred is acknowledged in carrying out the gas-fed electrode measurements. Helpful discussions are also acknowledged with Dr. Martin Shingler concerning the pyrochlore crystal structure.

\section{REFERENCES}

1. H. S. Horowitz, J. M. Longo and H. H. Horowitz, J. Electrochem. Soc., 130, 1851 (1983).

2. R. G. Edgell, J. B. Goodenough, A. Hammett and C. C. Naish, J. Chem. Soc., Faraday Trans. I, 79, 893 (1983).

3. H. S. Horowitz, J. M. Longo, H. H. Horowitz and J. T. Lewandowski, in "Solid State Chemistry in Catalysis", ACS symposium Series No. 279, R. K. Grasselli and J. F. Brazdil, Editors, pp. 143-163, American Chemical Society, Washington, D.C. (1985).

4. C. Iwakura, T. Edamoto and H. Tamura, Bull. Chem. Soc. Jpn., 59, 145 (1986).

5. J. A. R. Van Veen, J. M. Van Der Eijk, R. De Ruiter and S. Huizinga, Electrochim. Acta, 33, 51 (1988).

6. J. Prakash, R.E. Carbonio, M. Razaq, D. Tryk and E. Yeager, 173rd Meeting of the Electrochemical Society, Atlanta, GA, May, 1988, Ext. Abst., $88-1,503$ (1988).

7. H. S. Horowitz, J. M. Longo and J. T. Lewandowski, U. S. Patent 4,225,469, September 30, 1980.

8. H. S. Horowitz, J. M. Longo and J. T. Lewandowski, Mat. Res. Bull., 16, 489 (1981).

9. J. M. Longo, P. M. Raccah and J. B. Goodenough, Mat. Res. Bull., 4, 191 (1969).

10. H. S. Wroblowa, Y. C. Pan and G. Razumney, J. Electroanal. Chem., 69, 195 (1976).

11. W. O'Grady, C. Iwakura, J. Huang and E. Yeager, in "Proceedings of the Symposium on Electrocatalysis", M. Breiter, Editor, pp. 286-302, The Electrochemical Society, Pennington, NJ (1974).

12. R. D. Shannon and C. T. Prewitt, Acta Cryst., B25, 925 (1969).

13. M. Pourbaix, "Atlas of Electrochemical Equilibria in Aqueous Solutions," pp. 343-349, 373-377, Pergamon, Oxford (1966).

14. M. S. Hossain, D. Tryk, E. Yeager and A. Gordon, 171st Meeting of the Electrochemical Society, Philadelphia, PA, May 1987, Ext. Abst., 87-1, pp. 466. 


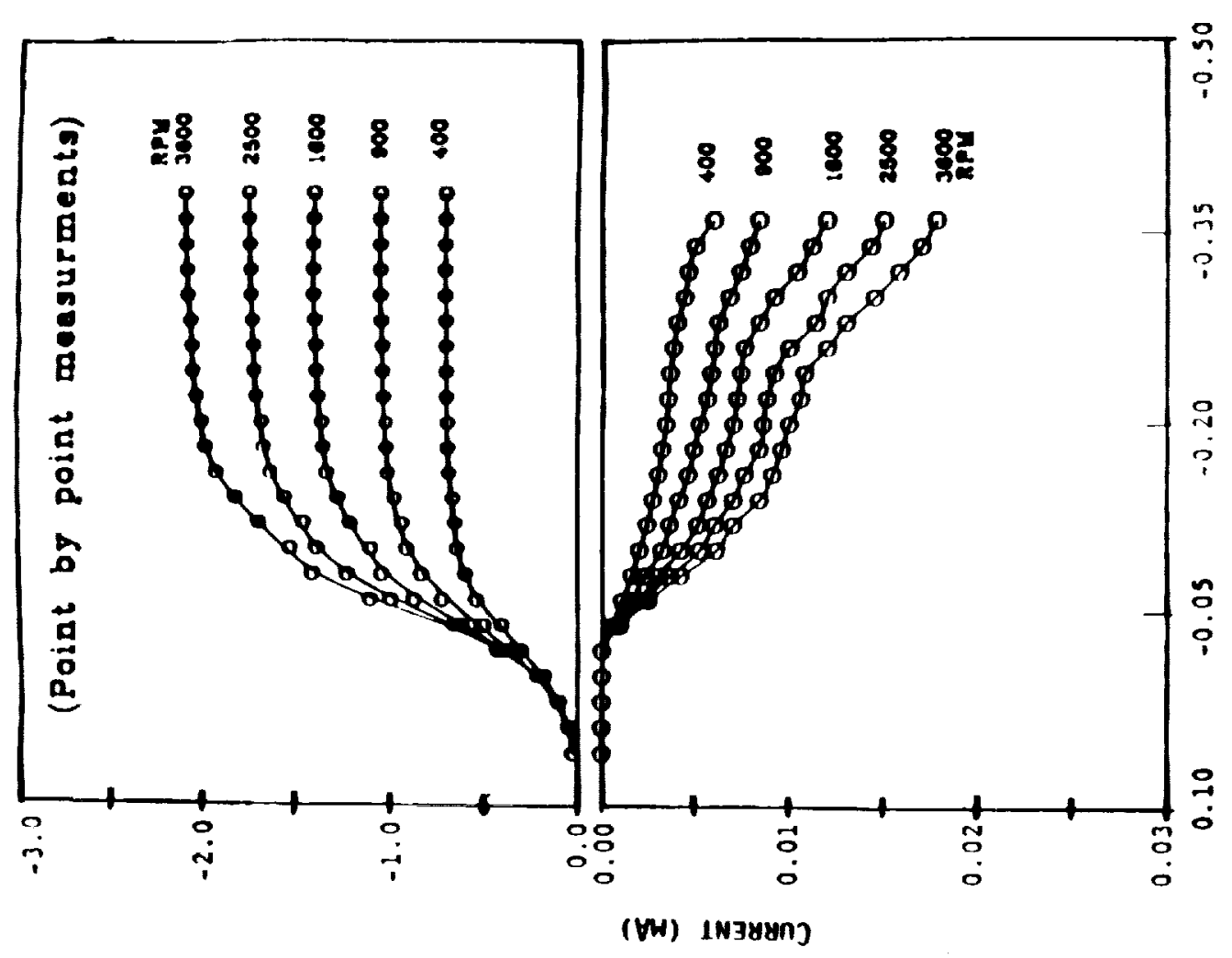

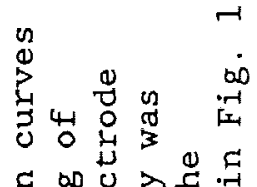
5 吅 雚 ᄃ I $\stackrel{\pi}{0} \stackrel{0}{0}$ हु 옳

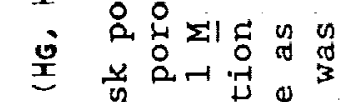

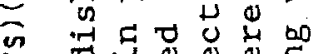
与 $\geqslant$ in ш क 次 म.

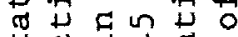
म둬 \& $\begin{array}{lll}0 \\ 0\end{array}$

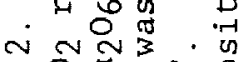
. 0 的只

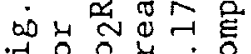
म्य

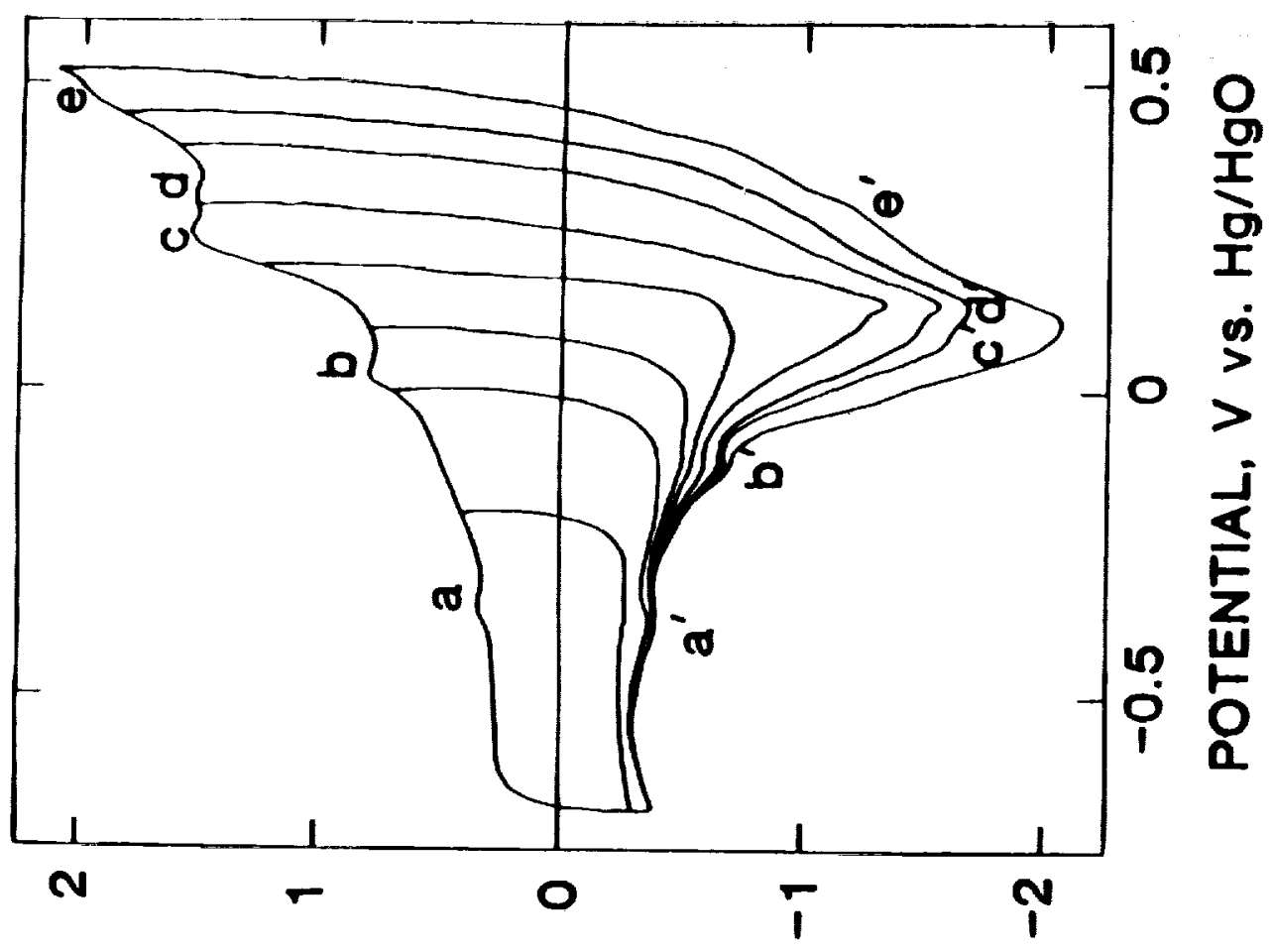

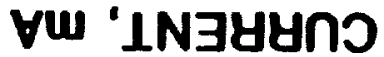

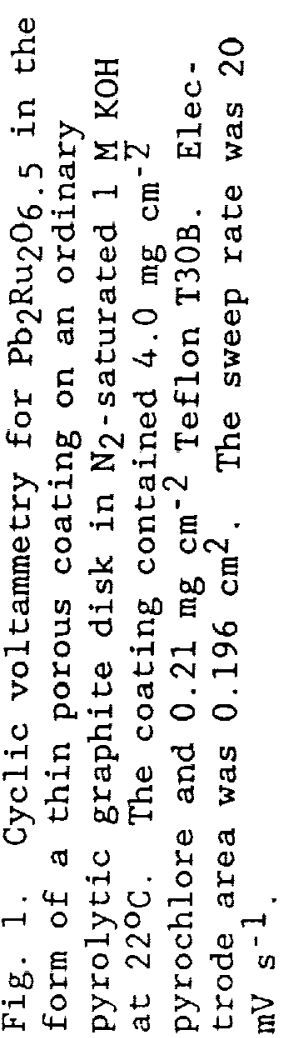




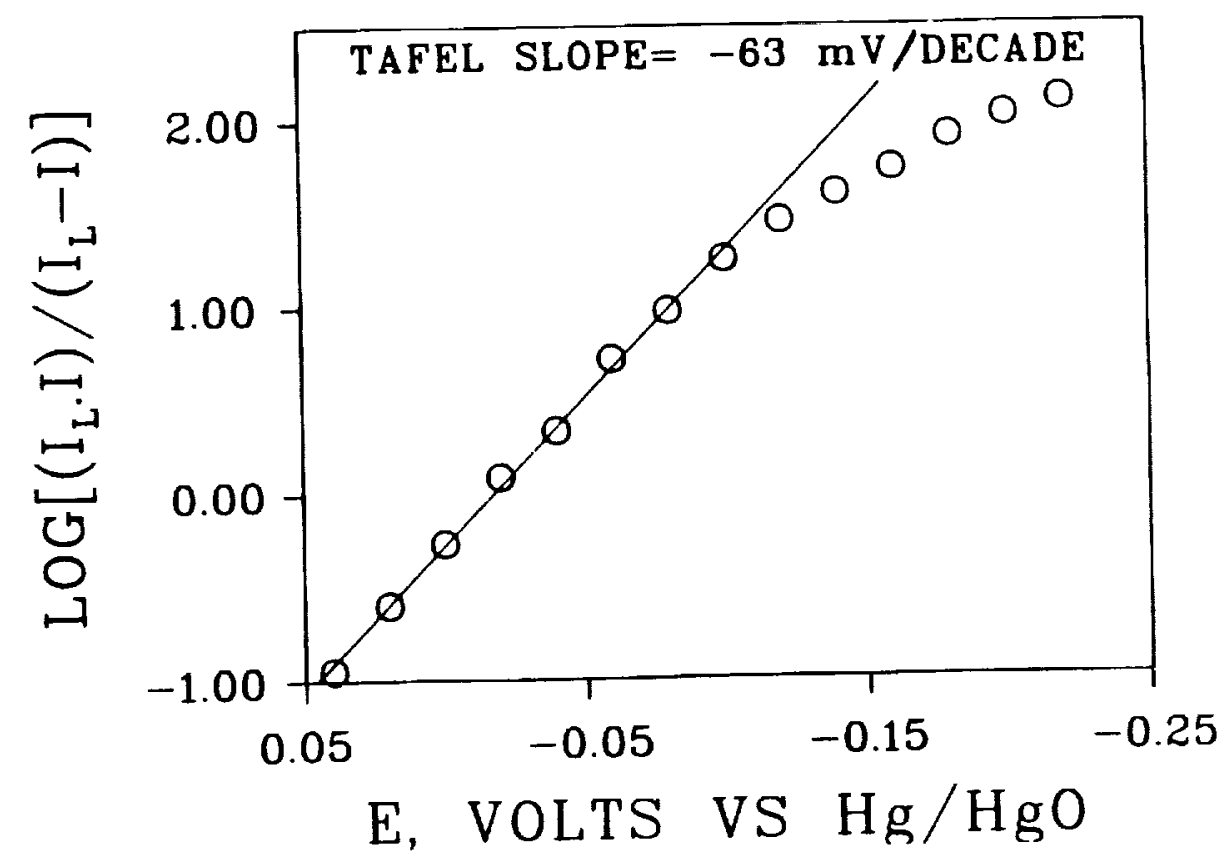

Fig. 3. Tafel plot for $\mathrm{O}_{2}$ reduction on $\mathrm{Pb}_{2} \mathrm{Ru}_{2} \mathrm{O}_{6} .5$ (thin porous coating) in $\mathrm{O}_{2}$ saturated $1 \mathrm{M} \mathrm{KOH}$. The current values (in $\mathrm{mA}$ ) for $2500 \mathrm{rpm}$ from Fig. 2 were corrected for mass transport using $\mathrm{I}_{\mathrm{L}}=1.75 \mathrm{~mA}$.

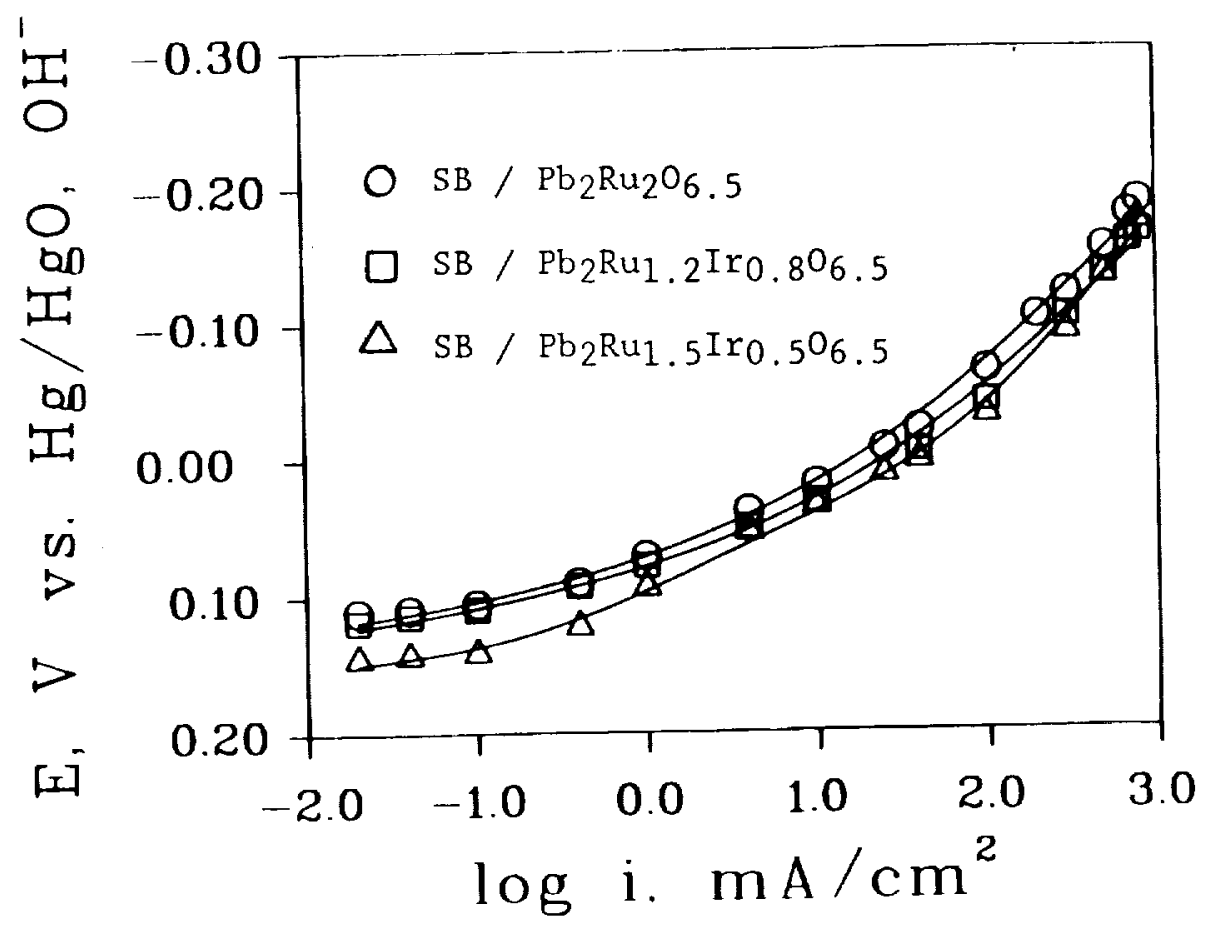

Fig. 4. Polarization curves for $\mathrm{O}_{2}$ reduction with porous $\mathrm{O}_{2}$-fed ( 1 atm) electrodes in $5.5 \mathrm{M} \mathrm{KOH}$ at $25^{\circ} \mathrm{C}$. The electrode contained $15.8 \mathrm{mg} \mathrm{cm}-2$ pyrochlore, $14.6 \mathrm{mg} \mathrm{cm}^{-2}$ air-oxidized Shawinigan black and $12.2 \mathrm{mg} \mathrm{cm}^{-2}$ Teflon T30-B and was heat-treated at $280^{\circ} \mathrm{C}$ for $2 \mathrm{~h}$ in flowing helium. 


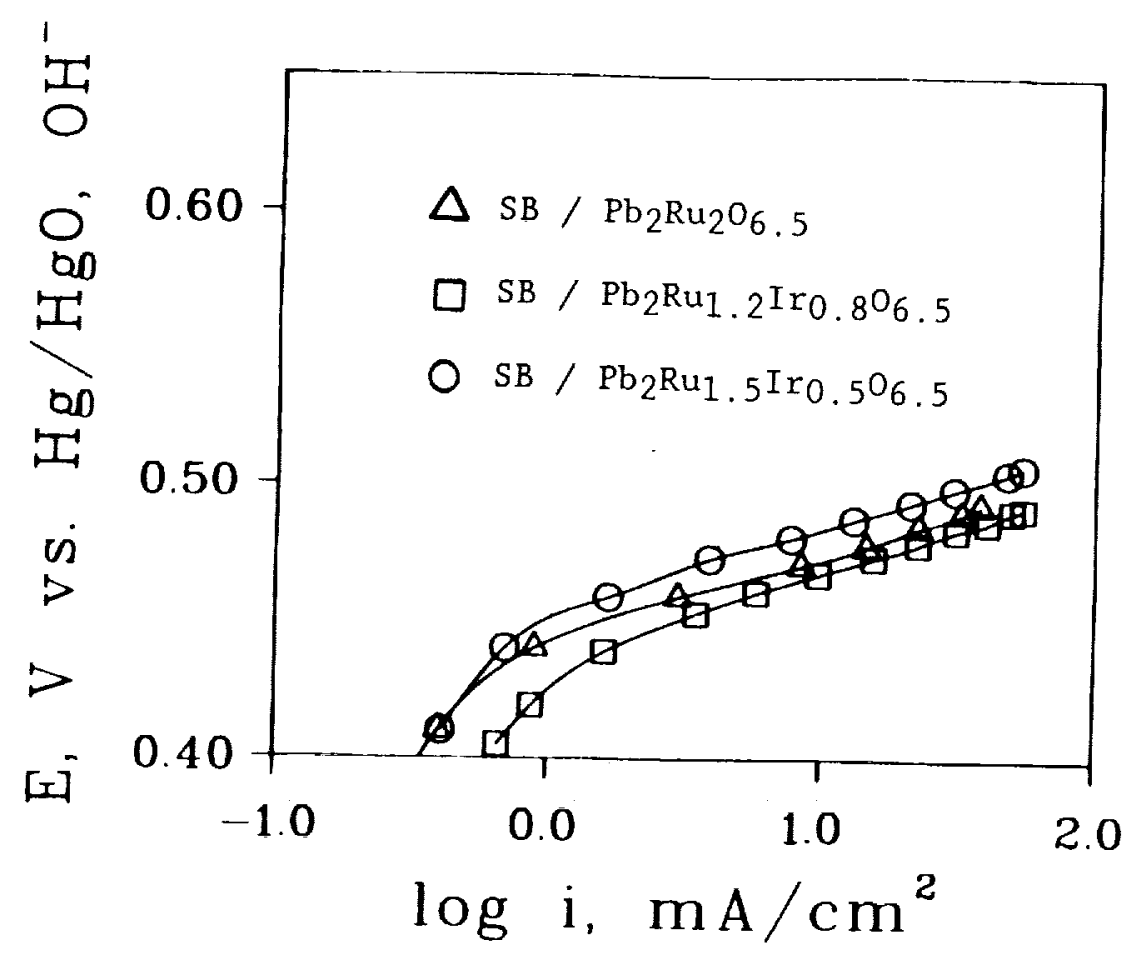

Fig. 5. Polarization curves for $\mathrm{O}_{2}$ generation with the porous electrodes of Fig. 4.

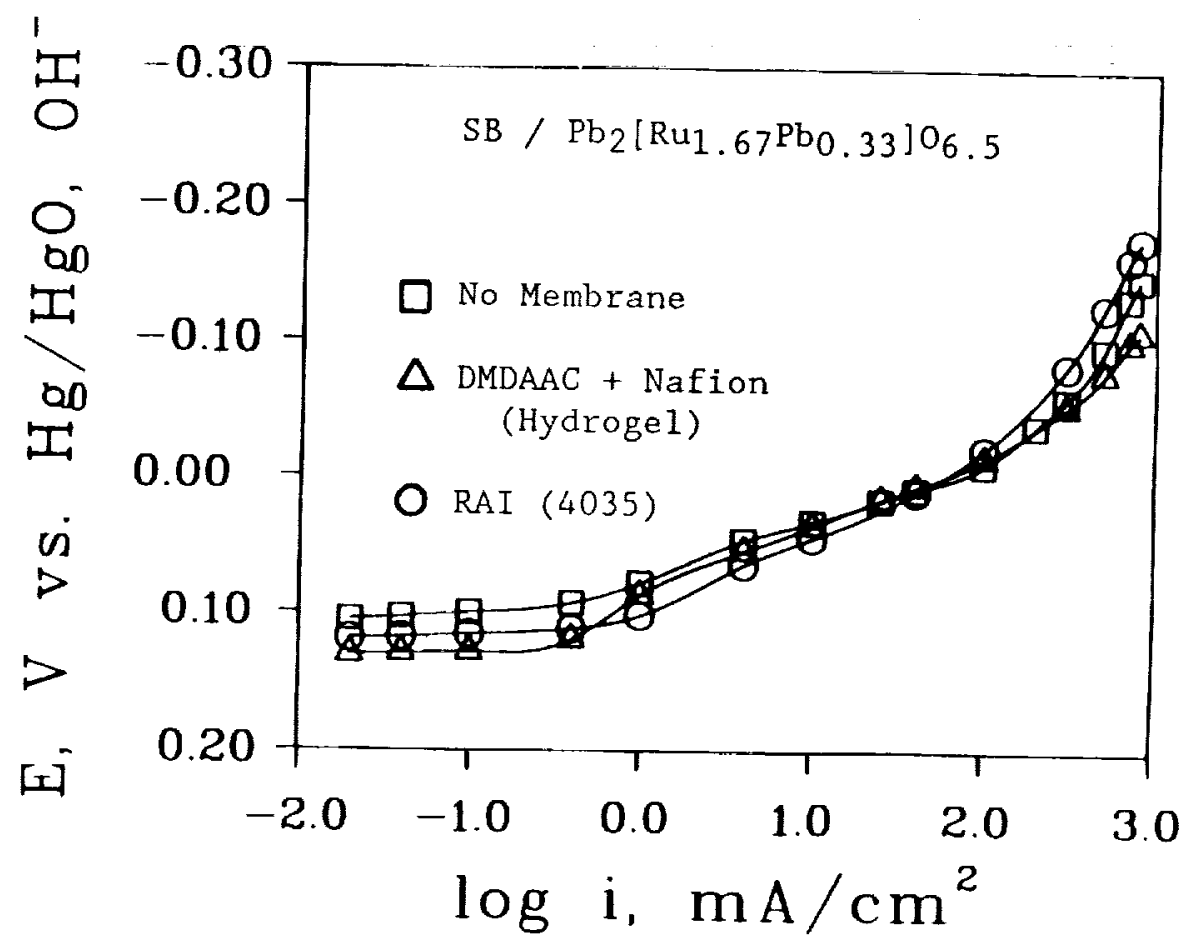

Fig. 6. Polarization curves for $\mathrm{O}_{2}$ reduction with porous $\mathrm{O}_{2}$-fed ( 1 atm) electrodes in $5.5 \mathrm{M} \mathrm{KOH}$ at $25^{\circ} \mathrm{C}$. The preparation of the hydrogel coating for curve 2 is described in the text. The RAI membrane was pressed onto the solution side of the electrode. 


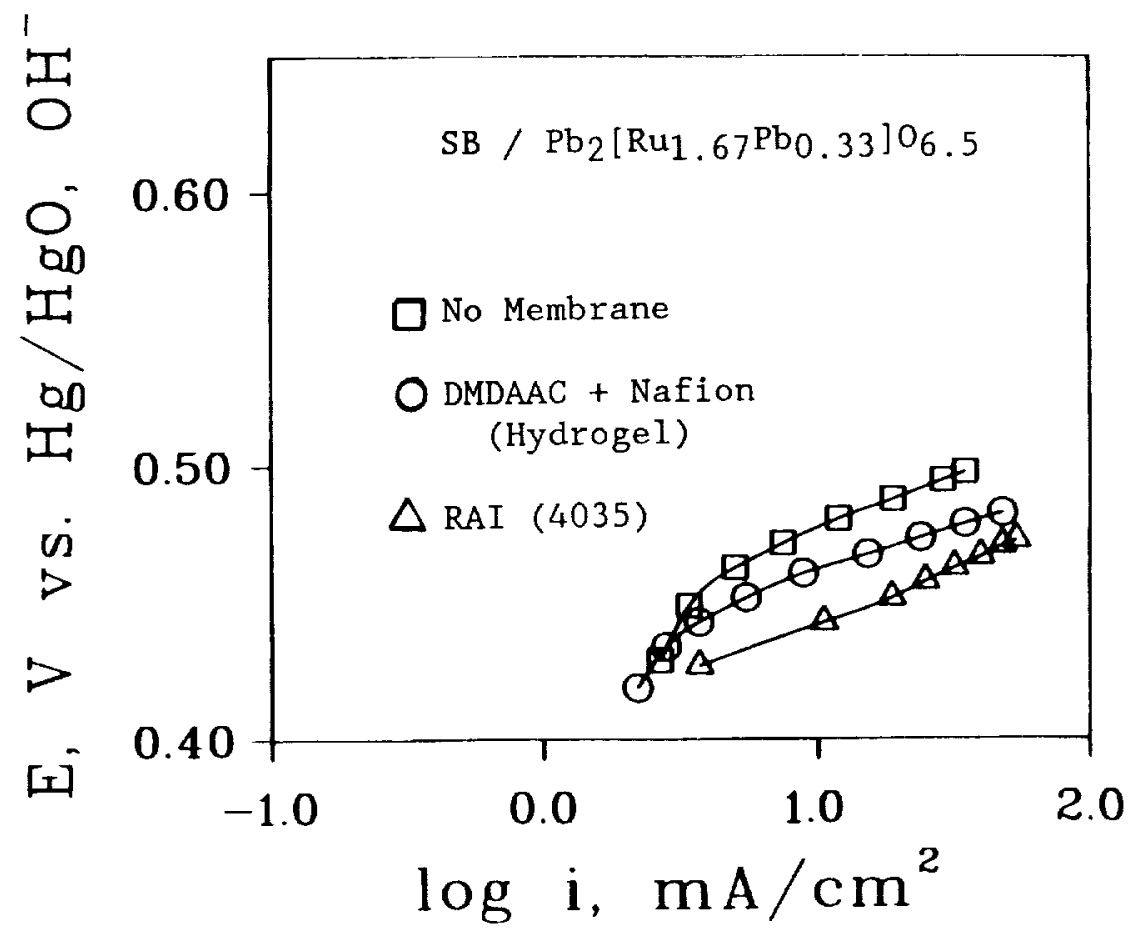

Fig. 7. Polarization curves for $\mathrm{O}_{2}$ generation with the porous electrodes of Fig. 6 . 


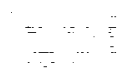

